\title{
Editorial
}

\section{O Trabalho entre o futuro e o passado}

Antes mesmo da Reforma da Previdência ser publicada, da destruição das normas de segurança e saúde no trabalho e do recente aprofundamento da reforma trabalhista, o mundo do trabalho em nosso país já estava afundando no pântano da precarização. E as coisas só pioram neste governo.

Não é por acaso que o Brasil foi incluído entre os dez piores países do mundo para trabalhar, ao lado de Bangladesh, Filipinas, Cazaquistão, Argélia, Arábia Saudita, Guatemala, Colômbia e Turquia e Zimbábue. Tal lista consta do Índice Global de Direitos, elaborado pela Confederação Sindical Internacional, a CSI-ITUC, mas talvez já esteja desatualizada e o nosso país tenha atingido situação ainda pior do que a maioria desses países.

Ao mesmo tempo que destrói o patrimônio público e desmonta as políticas sociais, o governo de extrema-direita prepara o trabalhador brasileiro para uma situação de semiescravidão na qual se deve festejar a "oportunidade" de conseguir um trabalho, qualquer trabalho, sem direitos além de uma remuneração suficiente para se manter sendo cada vez mais explorado.

No campo institucional, para este governo, não bastou a extinção do Ministério do Trabalho, pois, trata agora de extinguir as unidades da Fundacentro em vários estados, tomando suas sedes próprias, desmontando suas bibliotecas e inviabilizando as pesquisas em curso. Ainda estão sob sua sanha destruidora o Ministério Público e a Justiça do Trabalho.

Enquanto o mundo debate saídas para a crise econômica e a Organização Internacional do Trabalho - OIT divulgou, por ocasião do seu centenário, uma 
Declaração para o Futuro do Trabalho, que defende, dentre outros itens, que devamos buscar que todas as pessoas se beneficiem das transformações que ocorrem no mundo do trabalho, que se garanta uma relação de trabalho relevante sem interrupção, com proteção adequada de todos os trabalhadores, com desenvolvimento econômico sustentado, inclusivo e sustentável, pleno emprego e trabalho decente, o governo empurra o país no sentido oposto, excluindo direitos historicamente conquistados, inclusive de populações mais vulneráveis como os trabalhadores com deficiência.

O que está em jogo é se retrocedemos a mais de cem anos atrás, antes mesmo da criação da OIT e da regulação básica dos direitos do trabalho, ou nos preparamos para um nível mais elevado de desafios, valorizando o trabalho e sua proteção. Por ora, o passado está ganhando.

Nesta terceira edição da Laborare, estão presentes nos artigos científicos as inquietações sobre a onda precarizante que atinge o país.

Para Diego Leal, em seu artigo "Trabalhador autônomo exclusivo: maior segurança jurídica para o contratante ou melhor disfarce para a relação de emprego?”, a Reforma Trabalhista, ao criar a figura do trabalhador autônomo exclusivo, ampliou a incerteza acerca de significado deste no mundo do trabalho, aprofundando a precarização.

Eduardo Baptista Vieira, ex-coordenador da Escola Nacional de Inspeção do Trabalho, no artigo "A inobservância do princípio da proteção ao trabalhador pela reforma trabalhista", trata das violações feitas aos princípios da garantia da condição mais benéfica ao trabalhador e do "in dubio pro operário", afetando a essência do Direito do Trabalho e o "projeto civilizatório, humanístico e social" previsto na Constituição.

Atendendo convite da Laborare, o Professor René Mendes, um dos pioneiros da 


\section{Editorial: $O$ Trabalho entre o futuro e o passado}

Medicina do Trabalho no Brasil e renomado cientista, trata do "Futuro da Inspeção do Trabalho, enquanto política pública", analisando antes o atual lugar do trabalho na sociedade e na economia brasileiras, à luz das profundas modificações em curso, "ditadas pelas novas tecnologias pelo neoliberalismo sem limites e sem ética".

Com outro enfoque, mas também tratando da necessidade de se cumprir as normas de segurança e saúde, os autores Anastácio Gonçalves e Palmério Queiroz analisam a pior tragédia envolvendo o transporte marítimo no Estado da Bahia, destacando, além de aspectos técnicos envolvidos, os fatores relacionados às condições de trabalho inadequadas e à precariedade da embarcação.

Odete Pereira Reis, no artigo "A organização do trabalho, o risco psicossocial e o adoecimento", aborda as atividades bancárias e de teleatendimento, analisa as formas de gestão e organização do trabalho que "tem como base, entre outros, a cobrança de metas abusivas e o controle ostensivo dos trabalhadores, com o objetivo de intensificação do trabalho e o aumento contínuo de produtividade, e estudar as consequências para os trabalhadores advindas dessas práticas".

A Laborare é um investimento de quem acredita em um futuro de dignidade para o trabalho e que para alcançá-lo é preciso fazer ciência e diálogo, construir pontes entre os variados atores e atrizes do mundo do trabalho, resistir ao passado que insiste em arrastar suas correntes nesta noite que queremos seja passageira. Perseveraremos.

\section{Os Editores}

